\title{
Rethinking the subject in feminist research: narrative personae and stories of 'the real'
}

Maria Tamboukou, University of East London, UK

Abstract: In this paper I discuss the thorny issue of how we deal with the question of 'the death of the subject' within feminist narratology and beyond. In doing this, I bring forward the notion of the 'narrative persona', a configuration that I have come up with over the years that I have been writing feminist genealogies by drawing on women's auto/biographical narratives. The narrative personae of my inquiries emerge from Deleuze and Guattari's philosophy, and Arendt's political thought: they are taken as conceptual and aesthetic figures, who narrate and act and whose stories create a scene for dialogic exchanges, communication, understanding, ethical responsibility and action. In fleshing out the concept of the 'narrative persona', I draw on my research with women workers' narratives particularly focusing on Désirée Véret-Gay, the seamstress who founded the first feminist newspaper La Femme Libre in nineteenth century France. Her political writings in the form of letters, petitions and journal articles have become a significant body in the archives of feminist history. But although she lived a fully active political life she did not reveal much about her inner thoughts and passions, with the exception of a few letters that I will discuss in this paper entering into the dialogue of her epistolary discourse.

Key words: archives, epistolarity, feminist history, narrative personae, women workers

'I was born on April 4, 1810' ${ }^{1}$ Désirée Véret-Gay (1810-1891) wrote to the old friend and lover of her youth Victor Considerant, ${ }^{2}$ on 21 June, 1890 from Place St Gudule in Brussels. Her twelve letters to Considerant, sent between 1890 and 1891, are 'among the most beautiful and moving documents in the whole Considerant archive' ${ }^{3}$ historian Jonathan Beecher has noted in his extended studies of the Fourierist social movement. In this paper I look at Désirée's ${ }^{4}$ letters and political writings in an attempt to sketch a pen-portrait of a leading figure in the first autonomous feminist movement in nineteenth century France. Despite her prominence in the history of Western feminism, as well as her active involvement in the European revolutionary movements in the second half of the nineteenth century Désirée's papers have never beed assembled, recorded or organised, while her biography has yet to be written.

Désirée was born and grew up in turbulent times marked by fierce political uprisings, constitutional changes, radical economic development and intense labour activism. As a young proletarian girl working in the Parisian garment industry, she was amongst those workers who were involved in the European romantic socialist movements: Saint-Simonianism and Fourierism in France and Owenism in Britain. These 
movements and their influence on the political formations of modernity have been the object of numerous studies both in French and English historiographies. ${ }^{5}$ It was their egalitarian position vis-à-vis women, their focus on social issues and questions, as well as their pragmatic approaches to the idea of a new organization of work beyond class and gender divisions of labour that made their ideas so appealing to young proletarian women workers of the early industrial period. Looking back at her life, while living in solitude and almost blind in Brussels, Désirée would remember the revolutionary activities of her youth and her admiration for the followers of the Saint Simonian ideas:

I was searching the light and a thick veil was hiding it from my eyes.

However, I never despaired, I had faith [...] in a different world [and] here I am in this new world, the veil has fallen [...] my eyes have opened, I have seen a beautiful picture in the future. ${ }^{6}$

But disillusioned by the way the Saint Simonian hierarchy marginalised women, despite the egalitarian principles of their doctrine, ${ }^{7}$ Désirée detached herself from the movement as early as 1832: 'There is different work to be done. For me all social questions depend on women's freedom, ${ }^{8}$ she wrote in La Femme Nouvelle, the feminist newspaper that she had founded with her comrade and fellow worker MarieReine Guindorf only months before, in August 1832. It was around this time that Désirée turned to Fourierism and in spring 1833 she decided to move to London where she worked as a seamstress for almost two years. Her letters to Charles Fourier reveal that she did not enjoy her life in England: 'My nature has been broken and twisted by civilization. There is in me a chaos I cannot clarify; the longer I live, the more incomprehensible I find myself ${ }^{9}$ she wrote from 37 Duke St, Manchester Square in London.

Despite her difficulties in England, Désirée got involved in the Owenite circles and worked closely with Anna Wheeler ${ }^{10}$, 'who was like a second mother to me' ${ }^{11}$. On returning to France in 1834 she worked in Dieppe first in the women's clothing industry and then in Paris again, while remaining active in the Fourierist and Owenite circles. It was during this time that she had a brief affair with Considerant:

I guessed from the beginning your defects and your qualities and in spite of myself I loved everything about you. Nothing has escaped my memory: from your arrival at Paris in 1832 and your visit with Fugère up until the last time I saw you in 1837 at Robert Owen's rooms in the Hôtel de l'Angleterre. ${ }^{12}$

In 1837 Désirée married Jules Gay, who was Owen's translator and close follower, and had two sons, Jean in 1838 and Owen in 1842. Together they tried to found an infant school at Châtillon-sous-Bagneux in 1840; the school was to be based on Owen's pedagogical model of educating children in freedom, ${ }^{13}$ but the project did not succeed in the end, perhaps it was too much ahead of its time.

Désirée immersed herself in labour activism and later in the fierce politics of the February 1848 revolution. ${ }^{14}$ Together with Jeanne Deroin she contributed to the daily newspaper La Voix des Femmes between March and June 1848. She then became editor of the Politique des Femmes, which only published two issues and was closed down in the aftermath of the June 1848 uprising. After a second attempt to run the 
school at Châtillon-sous-Bagneux in 1848, Désirée resumed her work as a dressmaker and opened an atelier in the Parisian fashion street par excellence, rue de la Paix - a successful enterprise as her 'honourable mention' in the 1855 Paris international exhibition, testifies. ${ }^{15}$ However in 1864 she had to emigrate once more as her husband's editorial activities were considered unlawful: they faced a series of censorship attacks and they finally chose exile to avoid imprisonment. After a short time wandering in Europe, including Belgium, Switzerland and Italy, they eventually settled down in Brussels. During this period she got involved in the international labour movement and served as the temporary president of the women's section in the central committee of the First Workers' International, held in Geneva in $1866,{ }^{16}$ while in 1868 she published the book Éducation rationnelle de la première enfance: manuel à l'usage des jeunes mères in Geneva and London. ${ }^{17}$ Her ideas and impressions about labour politics in general and Belgium in particular are vividly expressed in her letter to Considerant:

The movement seen up close here as a whole, in this little Belgian country, is a curious thing to study insofar as it is a mixture of enthusiasm, sentiment and above all, the positivity that typifies the Belgian character [...] Once upon a time I used to say jokingly that Belgium was a mere baby. Now it is entering its virile passionate stage.' 18

Désirée must have died some time after July 1891, the date of her last extant letter, but we will never know for sure. It is also from her extant letters that we have learnt that she had outlived her husband and her two sons: 'I have a free spirit and I am independent due to the little fortune that my beloved sons and my husband have left me ${ }^{19}$ she wrote to Considerant. Although the seamstress who signed as JeanneDésirée, Désirée Véret, Désirée Gay and also Désirée Véret, veuve Gay, lived a fully active political life she did not reveal much about her inner thoughts and passions, with the exception of a few letters. Her political writings in the form of petitions, journal articles and letters have become a significant body in the archives of feminist history that cannot be restricted within the boundaries of Saint-Simonianism, Fourierism, Owenism, utopian socialism, or any other labels that have been attached to the European social movements of the nineteenth century. As I have argued elsewhere, it was her entanglement in the material conditions of her work as a seamstress that created conditions of possibility for her political ideas and practices to emerge and unfold, making connections with, but not reduced to the ideas and discourses of nineteenth-century romantic socialism. ${ }^{20}$ But apart from some biographical elements that I have traced across her documents and have roughly sketched above, is it possible to know more about Désirée, as indeed about many figures in the history of feminism? This is the question that I want to explore in this paper, by introducing the notion of the narrative persona as a mode of moving away from the post-structuralist 'death of the author' without losing some very important insights that discourse analytics have offered in the field of feminist narratology. The paper unfolds in 3 parts: following this introductory section, I give an overview of the philosophical underpinnings of the notion of the narrative persona and finally I look at Désirée's letters as traces of the historicity of her subject positions and as components in the assemblage of her desires, her words and her actions. 


\section{Conceptual and Methodological Entanglements}

In configuring Désirée as a narrative persona, I have followed Deleuze and Guattari's juxtaposition of conceptual personae in philosophy and aesthetic figures in art, as discussed in their last collective work, What is Philosophy? ${ }^{21}$ 'Philosophy constantly brings conceptual personae to life ${ }^{22}$ Deleuze and Guattari have suggested: the Socrates in Plato, the Dionysus in Nietzsche, the Idiot in Descartes becoming their exemplars for the most well-known conceptual personae in the history of philosophy. Conceptual personae become the subjects of philosophical enunciations, 'the becoming or the subject of a philosophy on a par with the philosopher'. ${ }^{23}$ The philosopher speaks through his/her conceptual persona, keeping a critical distance from what is being said and from the subject of enunciation. It is a third person, the conceptual persona, not the philosopher, that says I, since there is always a multiplicity of enunciations and subjects in the work of philosophy. In this light, Deleuze and Guattari explain that

the conceptual persona is not the philosopher's representative but, rather, the reverse: the philosopher is only the envelope of his principal conceptual persona and of all the other personae who are the intercessors [intercesseurs], the real subjects of his philosophy. Conceptual personae are the philosopher's 'heteronyms', and the philosopher's name is the simple pseudonym of his personae. $^{24}$

While philosophy invents conceptual personae, art creates aesthetic figures: 'the great aesthetic figures of thought and the novel but also of painting, sculpture and music produce affects that surpass ordinary affections and perceptions, just as concepts go beyond everyday opinions. ${ }^{25}$ Many of us share Mrs Dalloway's love of flowers, admire Les Demoiselles d'Avignon and are carried away by Carmen's passionate dance and singing. The way we connect with such aesthetic figures in literature, paintings and opera is different to our imaginary dialogues with Socrates or Dionysus. Conceptual personae and aesthetic figures, 'may pass into one another, in either direction' ${ }^{26}$ but should not be conflated Deleuze and Guattari note since 'the former are the powers of concepts, and the latter are the powers of affects and percepts. ${ }^{27}$

Emerging in passages and crossroads between conceptual personae and aesthetic figures, I have conceptualised Désirée as a narrative persona in a genealogical line of politically active seamstresses that shook France in the long durée of the nineteenth century. ${ }^{28}$ Indeed her letters, political writings, journal articles and books create a plane of consistency for the power of concepts - assemblages, becomings, neo-materialism - and the powers of percepts and affects - desires, pleasures and passions - to be charted. It is thus 'a third person', the narrative persona that says 'I' in the polyphonic narratives that comprise the archive of this study, allowing me as an author and a feminist narrative researcher to keep a distance from the narrator and indeed her narratives. In this context Désirée becomes a mediator through whom narrative as philosophy mobilises thinking and narrative as a feeling for the world produces affects.

But although my initial idea of the narrative persona comes from a synthesis of Deleuze and Guattari's notions of the conceptual persona of the philosopher and the aesthetic figure of the artist as explicated above, it is in Arendt's work that the 
notion has been politically grounded. As Arendt notes in her book On Revolution, the roots of the persona are to be found in ancient drama wherein it has a twofold function: a) as a mask disguising the actor in theatre and b) as a device that although disguising would allow the voice of the actor to sound through. ${ }^{29}$ If we follow the historicity of the notion however, in Roman times, the persona passes from the theatre to the legal realm where it means a legal personality, a Roman citizen and not any natural person. So what we have is: the drama persona and the legal persona.

In this context, the notion of the narrative persona in my analytics is taken as a conceptual and aesthetic figure, who acts and whose story we can follow in the pursuit of meaning and understanding. But the fact that we follow the story of the narrative persona does not necessarily mean that this story represents the real essence or character of who Désirée really was. This is not to deny that she was a real person, but to point to the limitations of hers and indeed anybody's personal and political narratives to convey the essence of who their author is. As Arendt has aptly put it: 'nothing entitles us to assume that [man] has a nature or essence in the same sense as other things' ${ }^{30}$ But the lack of essence does not necessarily lead to the death of the subject. While rejecting essence, Arendt theorises human existence, 'life itself, natality and mortality, worldliness, plurality and the earth', ${ }^{31}$ but here again she emphasises the fact that we are not reducible to the conditions of human existence. Instead of a unified and autonomous subject, there are nomadic passages and subject positions that the narrative personae of my inquiries take up and move between, while writing and/or visualizing stories of the self. Moreover, it is through their stories that certain concepts, ideas and events can be expressed, rehearsed and dramatised so that their enactment can create a scene for dialogic exchanges, communication, understanding and action.

Further considered within the legal dimension of the Roman tradition in Arendt's analysis, the narrative persona takes up a position in discourse and assumes her rights as a legal subject. This positioning does not essentialise her either; it rather creates a person with whom one can be in dialogue, but also to whom one is responsible: 'a right-and duty bearing person, created by the law and which appears before the law', as Arendt has pithily remarked. ${ }^{32}$ In the discussion of this paper, Désirée thus becomes a persona created by her narratives, but to whom I am accountable having taken up the responsibility of presenting her story as an Arendtian design that has a meaning; the latter is open to interpretation and negotiation between you as readers, myself as an author and narrative researcher and my narrative persona, whose stories should be open to all.

\section{Fonds}

During my archival research with Désirée's personal and political writings, the question of openness has particularly preoccupied me for different reasons and from different perspectives. To start with I was deeply upset to find out that although she was a notable figure in feminist labour history, her papers were never collected and archived and organized as fonds. This notion originated in France in 1841, when archivists were asked 'to unite all the deeds which come from a body, an establishment, a family, or an individual'. ${ }^{33}$ In this light, fonds were conceptualised as 
assemblages that were much more than a simple collection of papers; they included both substantial and contextual documents and charted authorial and discursive relations between private and public documents and the historical figures that had either originated them or featured in them. Seen from a Foucauldian critical perspective then, fonds flesh out the way documents connect within a collection, but they also expose hierarchical orderings, as well as power-knowledge relations at play. What I therefore suggest is that fonds create 'the order of the archive', which is how Désirée, alongside her other comrades, were excluded from their creation. Her letters and other articles are instead in the fonds of Saint-Simonian and Fourierist leaders Père Enfantin and Victor Considerant.

In thus addressing the question of openness, my first move was to create virtual fonds for Désirée Véret-Gay by bringing together existing biographical and autobiographical documents, archival sources, as well as publications from her and about her. ${ }^{34}$ What first emerged from this reassembling was the interesting phenomenon of what I have called 'the name wars', quite simply Désirée's decision to reject her patronymic name and choose her own name, Jeanne-Désirée, to sign her letters and articles. ${ }^{35}$ This is how my narrative persona explained her decision:

Men give birth to doctrines and systems and baptise them in their name; but we give birth to people; we should give them our own name and take only the name of our mothers and of God. This is the law dictated to us by nature and if we continue to take the names of men and of doctrines we will be slaves. ${ }^{36}$

Beyond the first move of creating Désirée's virtual fonds and engaging with the symbolic pluralism of her different names, my approach to reading and understanding her narratives emerged from an overall feeling that Niamh Moore, Andrea Salter, Liz Stanley and Maria Tamboukou have called archival sensibility. ${ }^{37}$ Archival sensibility encompasses a set of practices that highlight the need to study archival documents carefully, in the sense that they should not be simply treated as sources of nice quotations or as illustrations of an analysis that was not led by their study. Although we always go to the archive with some questions in mind, we should also let the narratives emerging from its documents surprise us, allow them to interrogate our apriori judgements, understandings and prejudices and let them redirect our analytical paths and routes of interpretation. Archival documents will always offer us exciting stories or quotations but their place should be formative and not illustrative or simply evidentiary in our narrative analytics.

But there is more to archival sensibility: although archival documents are often assemblages of fragmented, broken and discontinuous narratives, traces of the past rather than representations or mirrors of it, their fragmentation is not to be continued in the researchers' discourse. On the contrary we need to be sensitive to the lives of the documents found in the archive, try to understand and map the conditions of their possibility and attempt to imagine their lives before and after our encounter with them. Finally, we need to be sensitive to their potentiality, the forces and effects of their intensity, which we need to facilitate and set in motion, rather than block, hide or sidestep. Simply put, we cannot engage with documents of life while ignoring the life of documents within the archive and beyond. 
In this light I have been apprehensive of the danger of my narrative analytics stripping out the intensity of the stories that I have excavated in the archive of Désirée's papers. While trying to listen to some of the flickering stories that erupt from her documents, I have also allowed their order of discourse to mingle with my own interpretations and understanding. To do this I have created a virtual archival site, where apart from her fonds, I have carefully mapped the archival sources of my research, and wherever possible I have given links to the cited documents. ${ }^{38}$ In offering my readers the opportunity to study and appreciate the documents' poetics, textual economy and discursive order, I have attempted to open up a dialogical scene wherein the inevitable dryness of the researcher's analysis can be livened up in its entanglement with the stories of its narrative persona; it is to some glimpses into these stories that I now turn.

\section{Action and Narration: in struggle and in love}

When in the last women's session, I said that I do not want the Saint-Simonian name it is not at all because I deny the good that Saint-Simonians have done, neither do I doubt the good that they will do. [...] If I wanted to place myself under a name it would be certainly theirs that I would take.

But I feel that there is different work to be done. For me all social questions depend on women's liberation; she will resolve them all. It is therefore towards this aim that all my efforts tend. It is under the banner of the new women that I will relate everything I am doing for our emancipation. Women's cause is universal and it is no way only Saint-Simonian. ${ }^{39}$

With this article written on 4 November 1832 in the seventh issue of La Femme Nouvelle, Désirée publicly distanced herself from the Saint-Simonian movement she had so passionately embraced only two years earlier. It was the last article she wrote for the newspaper she had founded in August 1832. Among the many themes that have struck me when reading it, I was particularly impressed by the importance of the role of work in the first autonomous feminist movement. Indeed, what my overall analysis has shown is that 'the right to work' preceded 'the right to vote' in the histories of western feminism. Désirée's article in the first issue of the feminist newspaper outlines the importance of work in no uncertain terms: 'Young daughters of the people without any other knowledge than our religion and without any other resources than those produced with our needlework, we have begun a work, still small and obscure, but which will rapidly expand and will raise high political questions' ${ }^{40}$ In making this statement Désirée was aware of the material restrictions that her needlework imposed on the time and resources she could use for her political work, but she was also in the mood for leaping into radical futures. The notion of the importance of initiation, of making a new beginning was repeatedly flagged up in her articles, but it was mostly fleshed out in her decision to start a newspaper, the first to be written by [mostly] proletarian women only. As Suzanne Voilquin pithily put it in the last issue of La Tribune des Femmes in April 1834, Jeanne-Désirée 'was not the first to think of creating a women's newspaper, but was certainly the first to have the courage to do it'. ${ }^{41}$ 
Désirée was indeed courageous enough not only to initiate a feminist newspaper, but also to break her bonds with the Saint-Simonian movement when she realised that their doctrines and hierarchies had eventually excluded women, as we have already seen. But apart from being a feisty proletarian feminist, she was also a woman in love with the leader of the movement she was withdrawing from. Before breaking the ties with the Saint-Simonian circles, she sent a letter to Enfantin explaining the reasons for her detachment: 'I am of the people, as I always communicate with them when I see them gather in public squares ${ }^{\prime 2}$ she wrote. But despite her love for the people, which was immense and made her eyes 'fill with tears' ${ }^{43}$ she could also understand that not all Saint-Simonian men were embracing the idea of women's equal participation in the movement. It thus fell on women to organise for a better future: 'for us women, our work starts, to us women the duty to search for social love' 44 Désirée was adamant that women should look elsewhere, that they should stop following men, since what they had to say was 'so different from the nature of men'. ${ }^{45}$ In writing to Enfantin about the need for women's autonomous organisation, she was open and frank about the emotional difficulties of this decision. And yet her letter to the Saint-Simonian leader was a definitive adieu:

It is something stronger than my will that makes me write to you [...] yet you are the only one with whom I can be free [...] I am strong enough to endure your frankness and your advice and I am not afraid any more of the influence that can interfere with my work [...] Farewell, I embrace you and all humanity! ${ }^{46}$

But while celebrating the importance of work as a creative force of life and political action, Désirée was also critical of the drudgeries of industrial labour. Her letters to Charles Fourier from Manchester Square in London paint a grim image of a proletarian women's life in the early phases of the industrial revolution:

The work is so unappealing that I would prefer to be in the galleys. We must work from seven in the morning until midnight at the earliest; you see there are only very short breaks during the day, so we don't really have time to eat and we are subjected to the varying caprices of the stock market; oh what a stupid business is this, this civilised industry! ${ }^{47}$

Not only was the young seamstress disillusioned and frustrated by capitalist exploitation, she had also come to interrogate some of Fourier's ideas about the power of love:

You expect, my dear M. Fourier, that love will come along to distract me, the love of an Englishman, isn't this what you are thinking? In this they are the same as they are in mechanics. They can only handle the material side or a fanciful love that exists only in the imagination. I have had lovers here, I can confide this to you, but they have only given me sensual pleasures. The English are cold, egotistical, even in their pleasures, in making love, in dining. Everyone thinks only of himself. Never shall I have the sort of love I properly need. I have made my decision about it and have settled for pleasure. ${ }^{48}$

Désirée's sincere and lively letter to Fourier forcefully throws us into a material and grounded understanding of the affective forces that traversed the constitution of the 
narrative persona, as already discussed above. It was love as Eros, passion and desire, a force for life, a mutual recognition, a movement towards the other that Désirée was missing. In downplaying pleasure in the narrative persona's epistolary discourse I do not want to imply, let alone suggest that Désirée did not experience pleasure in her life: her letter above is a testament to the opposite. But what also emerges from her discourse around desire, love and pleasure is that pleasure was for her a notion heavily invested and indeed constrained by the segmentarities of capitalism and patriarchy. It was only by following forces of passion and desire that she could envision a radical future. Her letters to Fourier thus opened up different spaces in the misery of her life in England and powerfully show that it was despite and not because of pleasure that she went on working, writing fighting and dreaming:

My dear Mr. Fourier, if you were not a great genius, I would never dare write such silly things to you. I leave my pen roam free, certain that nothing can be lost with you and that, amid the complaints of this poor civilised creature, you will find a few seeds that will create a happy harmony between the pivot of my thoughts and your theory. This will be the only thing that will draw me out of my apathy and I always think about it in happiness; but a dry theory is only good for the spirit, I am therefore impatient to grow old, so that I can see the dawn of its materialisation. ${ }^{49}$

Désirée did indeed grow old to see the dawn of a different world for workers, but not so much for women. Writing to Considerant from Brussels she remembered Fourier's love as reciprocal recognition, as well as the soothing impact that their correspondence had upon her life as a struggling young seamstress, who was still dreaming of happiness:

On the occasion of every anniversary of those who have gone, I need to remember them, be reflective. Fourier was the console of pains; for me as for the others he loved. My youth, my social enthusiasm, my inexperience of life, inspired him to put reasoning into theory and track the reason of my sadness. 'You have so many dominant passions', he wrote to me and would urge me to believe in civilisations. ${ }^{50}$

Throughout her life Désirée let her passions dominate her, perhaps this is why she kept her revolutionary spirit high even when she got married and had two children. 'We cannot die without finishing the work that has been at the heart of our whole existence ${ }^{51}$ she wrote to Enfantin on 8 February 1848, shortly before she joined the demonstrations and street fighting. The February revolution ${ }^{52}$ initiated processes for the creation of a new body politic and it was in the revolutionary spirit of the days that Désirée took to the streets again, demanding that women workers should be part of the struggle for democracy; in linking the right to work with the right to vote she worked simultaneously for both:

Citizens,

Many isolated women are in a desperate situation, you will not want them to continue to be exposed to poverty or disorder. Good morals are the strength of the republics, and it is women who make the morals; the nation should honour women's work through your voice! With your will they should take part in the 
reorganisation that occurs; and you should encourage the principle of association for the work they do within their control. ${ }^{53}$

In gendering the February revolution's right to work, Désirée highlighted the necessity for women's work to be recognised and honoured. She particularly emphasised the fact that many women workers were isolated and indeed marginalised and erased within the deplorable conditions of home based work. As a counter action to isolation Désirée would flag up the principle of association retrieving it from the theoretical baggage of the romantic socialist movements of her youth. Her correspondence with Enfantin between January and April 1848 shows that it was not just memories that moved her actions: her present was fused with the ideas of her political actions in the past, enriched by the experiences of a fully active life. ${ }^{54} \mathrm{In}$ doing so she wrote against two real and discursive separations: the social and the political, as well as the private and the public. She was determined that a reorganisation of the public sphere of work was dependent upon a reorganisation of the private sphere of the family and that the two could not be separated: 'we urgently need to create national restaurants, as well as laundries and lingeries, where people can find cheap healthy food and orderly and clean care, which cannot be created in isolation and which women reunited in association can easily organise', ${ }^{55}$ she argued.

During the time of the February revolution Désirée wrote fiery articles in La Voix des Femmes first and then in La Politique des Femmes. What she mostly highlighted in her articles was the fact that although women's political aim was the same with men's, their perspective was different and thus 'we must each have our originality', so that 'under the vast banner of socialism women's politics can march in front alongside men's politics. ${ }^{56}$ La Politique des Femmes did not publish more than 2 issues as the very possibility of being involved in politics was denied to women by law in the summer of 1848. Désirée followed Deroin in editing L' Opinion des Femmes, but the continuing persecutions and political failures eventually took their toll on her enthusiasm and commitment. At the end of 1849 she had retreated from public life and she was eventually forced to take the route of voluntary exile in 1864, following her husband Jules Gay who had lost his permit to publish in France. In one of her last letters to Considerant she wrote about her life in dark times: 'I didn't use to like either Belgium, or the Belgians. I moved here against my will [...] And, well, now that I am as free as I have never been, I live here voluntarily and I feel more and more attached to them, having learnt to know them. ${ }^{57}$ Having written profoundly and tenderly about her life in exile, Désirée gave away the mystery of her passionate involvement and also of her recurrent disappearances from the editorial and activists' groups as well as the workers' associations she had so tirelessly work to put together: 'After the struggle I used to fly off into the clouds of reverie, where I fashioned an ideal world for myself. Real, earthly life has always been painful for me' ${ }^{58}$, she wrote to Considerant in July 1891, shortly before she died. But what does it mean to escape 'the real'? It is on some reflections on how the figure of the narrative persona contributes to new modes of making sense of the subject that I now want to conclude this article. 
Post-structuralist approaches to the subject in feminist theory and beyond have acknowledged and indeed celebrated multiplicity, fragmentation, non-fixity and nomadism, but they have avoided or side-stepped the effects of 'the real', simply put the material components that are entangled in the discursive constitution of subjectivities. In this context Katerina Kolozova has pointed to 'the need in twentyfirst century continental philosophy to traverse the postmodern or poststructuralist limits of thought. ${ }^{59}$ Kolozova's take of 'the real' follows trails of Francois Laruelle's notion of le vécu, ${ }^{60}$ the real as lived experience and not as the impossibility of its psychoanalytic take, mostly recognised in Judith Butler's influential theorisation of subjectivity. ${ }^{61}$ 'The real does not take the form of the meaning that is ascribed to it ${ }^{\text {' }}$ ' Kolozova notes, since 'as soon as it becomes a meaning, it retreats as the real. ${ }^{63}$ It is precisely at this point that the configuration of the narrative persona has made a contribution. Although 'the real' fades away at the moment of its discursive inscription, it nevertheless leaves its traces in the stories that have revolved around le vécu. We have thus seen instances of 'the real' flickering in the epistolary narratives that Désirée wrote at the end of her life. What has also emerged from these narratives is a remembered unity of the self, a design of a life that has a meaning. It is the possibility of having a unity, albeit only in narrative terms, that the move beyond the post-structuralist denial or rejection of it allows for, through the configuration of the narrative persona.

As I have shown in this article, Désirée has emerged as a narrative persona through her memory journeys that she passionately retraced in her last letters to a comrade and lover of her youth. Her very first letter to Considerant in May 1890 vividly inscribes her will, but also her ambivalence and hesitation in drawing a pen-portrait of herself through triggering the memory of her addressee: 'Does Victor Considerant remember Jeanne-Désirée? If yes, he should write her a word. She has forgotten nothing, neither Fourier, nor the feelings of the 1832 youth, and in her voluntary solitude, she lives calm and her heart is filled with memories of all her passionate life'. ${ }^{64}$ In using the third-person mode of address Désirée created a space of both intimacy and distance in her epistolary relationship; she would never use it again in the rest of their correspondence that marks the last year of her life. Love moves Désirée's memory journeys in her letters to Considerant, but although it is related to le vécu, the lived experiences of her amorous relationship to one of the leaders of the Fourierist movement it is not dependent on it. It is rather conceived in unilateral terms, love as 'radical solitude' in Kolozova's theorisation. ${ }^{65}$

Désirée's sense of continuity at the end of her life that can only be traced in her epistolary narratives does not create an essence of the self, but it does mark a 'stance'; ${ }^{66}$ it becomes the vector of her conatus, the Spinozist will to go on living. 'There is an instance of continuity of the "I" provided by the incessant effort of the body to preserve itself against the disintegration brought about and upon it by the subject', Kolozova has argued. ${ }^{67}$ It is this 'I' that persists through the material continuity of its body and its lived experiences that emerges as the narrative persona of my understanding and analysis. Although I will never find 'the truth' about who Désirée 'really was', I have taken responsibility vis-à-vis 'the real' of her lived experiences, which I have traced, reassembled, reread and effectively 
rewritten, creating a form for her narrative persona to take a position in the archives of feminist history.

${ }^{1}$ Désirée Véret, veuve Gay to Victor Considerant, letter dated, 21 June, 1890. Archives Nationales Archives Nationales de France, Fonds Fourier et Considérant, Correspondance des membres, Dossier 8, Lettres de Désirée Véret, veuve Gay (AnF/10AS42/8/DVG/59/2.)

${ }^{2}$ Victor Considerant (1808-1893) was a follower of Charles Fourier's ideas and a significant historical figure in the movement of French Romantic Socialism. See Jonathan Beecher, Victor Considerant and the Rise and Fall of French Romantic Socialism (Berkeley: University of California Press, 2001) for a rich intellectual biography.

${ }^{3}$ Beecher, Victor Considerant, p. 441.

${ }^{4}$ As I will discuss further on in this paper, Désirée used a range of different names to sign her personal and public writings. For the sake of clarity I have thus chosen to use her first name only, although I return to the issue of names in the history of feminism, later on in the paper.

${ }^{5}$ See Maria Tamboukou, Sewing, Fighting and Writing: Radical Practices in Work, Politics and Culture (London: Rowman and Littlefield, 2015) for an overview of this literature.

${ }^{6}$ Désirée to Enfantin, letter dated 11 September, 1831, p.1. Bibliothèque de l'Arsenal, Fonds Enfantin, Ms7608/Correspondance du Globe (Dames)/Désirée (J.)/4 lettres/40(1) [in microform] (BnF/BdA/FE/Ms7608/CdG(D)/DJ/40,1).

${ }^{7}$ There is a rich body of literature around Saint-Simonianism, see Pamela Pilbeam, Saint-Simonians in Nineteenth Century France: From Free Love to Algeria (Basingstoke: Palgrave, 2014) for an updated overview of this literature. 8 'From my work you will know my name', Apostolat des Femmes-La Femme Nouvelle, 1(7), 69-70, November 4, 1832. As I have discussed elsewhere in detail, this newspaper, which was initially named La Femme Libre, changed many names during the two years of its publication and I have tried to keep the historicity of these name changes in the citation. See Tamboukou, Sewing, Fighting and Writing, particularly Chapter 3.

${ }^{9}$ Désirée to Charles Fourier, letter dated 14 August, 1833, transcribed and published by Michèle Riot-Sarcey, 'Lettres de Charles Fourier et de Désirée Véret : une correspondence inédite'. Cahiers Charles Fourier 6, 3-14 (1995), p.6.

${ }^{10}$ Anna Wheeler (1780-1848) was a political writer and passionate supporter of women's rights. She was a friend of the French Socialists and often travelled and worked in France. For more details about Wheeler's life and work, see amongdt others, Karen Offen, European Feminisms 1700-1795: a Political History, Stanford, Ca: Stanford University Press, 2000.

${ }^{11}$ Désirée to Considerant, letter dated, 7 September, 1890.

(AnF/10AS42/8/DVG/62/2)

${ }_{12}$ Désirée to Considerant, letter dated, 2 October, 1890, (AnF/10AS42/8/DVG/64/2)

${ }^{13}$ For Owen's educational ideas, see amongst others, Ian Donnachie, Robert Owen, Owen of New Lanark and New Harmony (East Linton: Tuckwell Press, 2000). 
${ }^{14}$ There is a rich body of historical studies around the February 1848 revolution, which initiated the Second Republic in the French political history. De Tocquevilles' Recollections is considered to be the classic source. See Alexis De Tocqueville, Recollections: The French Revolution of 1848, edited by J.P Mayer and A.P. Kerr, translated by George Lawrence (New Brunswick: Transaction Publishers, 2009 [1969]).

${ }^{15}$ See, letterhead of Désirée's letter to Enfantin, dated May 28, 1856: 'Exposition Universelle 1855, Mention Honorable, Mme Gay, Modes, Rue de La Paix 19', Bibliothèque Nationale de France (BnF), Bibliothèque de l'Arsenal (BdA), Fonds Enfantin ou Fonds Saint-Simonien, Ms7608/Correspondance du Globe (Dames)/Désirée (J.)/4 lettres/40-43 [in microform], (BNF/BdA/FE/CD/7728/163). ${ }^{16}$ Désirée to Considerant, letter dated, 17 September, 1890, (AnF/10AS42/8/DVG/63/2).

${ }^{17}$ Désirée, Gay, Éducation rationnelle de la première enfance: manuel à l'usage des jeunes meres (Paris: Adrien Delahaye Libraire and Geneva: J. Gay et Fils, 1868).

${ }^{18}$ Désirée to Victor Considerant, letter dated 3 October, 1890, (AnF/10AS42/8/DVG/64/3).

${ }^{19}$ Désirée to Considerant, letter dated, 21 June, 1890 (AnF/10AS42/8/DVG/59/2)

${ }^{20}$ SeeTamboukou, Sewing, Fighting and Writing. .

${ }^{21}$ Gilles, Deleuze and Felix, Guattari. What is Philosophy? Translated by Graham Burchell and Hugh Tomlinson (London, New York: Verso, 2004).

${ }^{22}$ Deleuze and Guattari, What is Philosophy? p.62.

${ }^{23}$ Deleuze and Guattari, What is Philosophy? p.64.

${ }^{24}$ Deleuze and Guattari, What is Philosophy? p.64.

${ }^{25}$ Deleuze and Guattari, What is Philosophy? p.65.

${ }^{26}$ Deleuze and Guattari, What is Philosophy? p.177.

${ }^{27}$ Deleuze and Guattari, What is Philosophy? p.65.

${ }^{28}$ SeeTamboukou, Sewing, Fighting and Writing. .

${ }^{29}$ Hannah, Arendt, On Revolution (London: Penguin, 1990), p.106.

${ }^{30}$ Hannah, Arendt, The Human Condition (Chicago: University of Chicago Press, 1998[1958]), p.10.

${ }^{31}$ Arendt, The Human Condition, p.11.

${ }^{32}$ Arendt, On Revolution, p.107.

${ }^{33}$ Sharon, Thibodeau, 'Review of The Archival Fonds: From Theory to Practice, edited by Terence Eastwood, Archivaria, 36, 256-8 (1993), p.256.

${ }^{34} \mathrm{See}$ https://sites.google.com/site/mariatamboukou/the-book-archive/virtualfonds/desiree-veret-gay [Accessed 6-6-2018]

${ }^{35}$ This was a collective decision that all the editors and the majority of the contributors of the first feminist newspaper followed. See Tamboukou, Sewing,

Fighting and Writing.

${ }^{36}$ Apostolat des Femmes-La Femme Nouvelle 1(7), 70. November 4, 1832.

${ }^{37}$ Niamh Moore, Andrea Salter, Liz Stanley and Maria Tamboukou, The Archive Project: Archival Research in the Social Sciences (Farnham: Ashgate, 2016).

${ }^{38} \mathrm{See}$ https://sites.google.com/site/mariatamboukou/the-book-archive/archival-worlds

${ }^{39}$ Apostolat des Femmes-La Femme Nouvelle 1(7), 69, 4 November, 1832. (my emphasis).

40 Apostolat des Femmes-La Femme Nouvelle 1(5), 36, 8 October, 1832.

${ }^{41}$ Tribune des Femmes 11(2), 181. April, 1834.

${ }^{42}$ Désirée to Enfantin, letter dated, 20 October, 1832, $\mathrm{BnF} / \mathrm{BdA} / \mathrm{FE} / \mathrm{Ms} 7608 / \mathrm{CdG}(\mathrm{D}) / \mathrm{DJ} / 43$, p.1. 
${ }^{43}$ D to Enfantin, 20 October, 1832, p.1.

44 J-D to Enfantin, 20 October, 1832, p.2.

${ }^{45}$ Désirée to Enfantin, 20 October, 1832, p.3.

${ }^{46}$ Désirée to Enfantin, 20 October, 1832, pp. 3-4.

${ }^{47}$ Désirée to Charles Fourier, undated letter, written from 37 Duke Street, Manchester Square in London, cited in Riot-Sarcey 'Lettres de Charles Fourier et de Désirée Véret', p.6.

${ }^{48}$ Riot-Sarcey 'Lettres de Charles Fourier et de Désirée Véret', p.7.

${ }^{49}$ Riot-Sarcey 'Lettres de Charles Fourier et de Désirée Véret', p.8.

${ }^{50}$ Désirée to Considerant, letter dated, October 9, 1890. (AnF/10AS42/8/DVG/66/1)

${ }^{51}$ Désirée to Enfantin, letter dated 8 February 1848, (BnF/BdA/FE/CD).

52 There is a rich body of historical studies around the February 1848 revolution with de Tocquevilles' Recollections (2009) being the classic source. See also Jones 1991 for the wider context of the 1848 European revolutions.

${ }^{53}$ Petition addressed by Désirée Gay to Louis Blanc on March 2, 1848; reprinted in La Voix des Femmes, (2), 2, March 22, 1848.

${ }^{54}$ There are 14 extant letters from Gay to Enfantin between 1846 and 1860 and 6 of them were written between January and April 1848: January 1; February 8, 25, 26;

March 7 and April 4. (BnF/BdA/FE/CD/7728/151-164)

${ }^{55}$ Petition addressed by Désirée Gay to Louis Blanc on March 2, 1848; reprinted in La Voix des Femmes, (2), 2, March 22, 1848.

${ }^{56}$ La Voix des Femmes, (2), 2, March 22, 1848.

${ }^{57}$ Désirée to Considerant, letter dated, September 1, 1890

(AnF/10AS42/8/DVG/61/1-3).

${ }^{58}$ Désirée to Considerant, letter dated, July 6, 1891. (AnF/10AS42/8/DVG/68/3)

${ }^{59}$ Katerina Kolozova, Cut of the Real, Subjectivity in Poststructuralist Philosophy (New York: Columbia, University Press, 2014), p. 1.

${ }^{60}$ François Laruelle, Introduction au non-marxisme (Paris: Presses Universitaires de France, 2000).

${ }^{61}$ See Judith Butler, The Psychic Life of Power: Theories in Subjection (Stanford: Stanford University Press, 1997)

${ }^{62}$ Kolozova, Cut of the Real, p.5.

${ }^{63}$ Kolozova, Cut of the Real, p.5.

${ }^{64}$ Désirée to Considerant, letter dated, May 5, 1890, (AnF/10AS42/8/DVG/57/1).

${ }^{65}$ Kolozova, Cut of the Real, p.11,

${ }^{66}$ Kolozova, Cut of the Real, p.47.

${ }^{67}$ Kolozova, Cut of the Real, p.48. 